\title{
13
}

\section{Norway: Public Debate and the Management of Petroleum Resources and Revenues}

\author{
Indra Overland
}

\section{Introduction}

The Norwegian petroleum era started with a request from Phillips Petroleum for permission to conduct geological exploration off the Norwegian coast in 1962. In 1965, the first licensing round was carried out, and in 1969 the large Ekofisk oilfield was discovered. Along with ensuing discoveries, this led to a rising wave of petroleum revenue, which was further inflated by the two oil crises in the 1970s and the steady expansion of Norwegian oil extraction.

To put the income into perspective, there have been periods when Norway - a country with a population of only five million-was one of the world's top three oil exporters (Steigum 2002, 5). In many other countries, such windfalls have been associated with the problems

\section{Overland $(\bowtie)$}

Head of the Energy Programme, Norwegian Institute of International Affairs, Oslo, Norway 
referred to as the 'resource curse'. In Norway, things worked out differently. As of 2016, the country had one of the lowest unemployment rates in Europe, the highest Human Development Index value in the world and a sovereign wealth fund worth USD 840 billion (NBIM 2017). Many skilled jobs for locals had been created in the oil and gas industry. Despite the constant pressure from Dutch diseasethrough which general production costs are driven up, making it too expensive for a country to produce much else than oil and gasNorway retained other export industries. At the political level, Norway remained a stable and well-functioning democracy and was rated the sixth least corrupt country in the world (Transparency International 2015). Somehow Norway managed to largely escape the resource curse.

In the introductory chapter, I presented the hypothesis that the existence of well-designed institutions alone is insufficient for successful resource management and therefore cannot explain Norway's relative success. I proposed that the creation, performance and evolution over time of such institutions also depends on having a social and political context like the Norwegian one, including a diverse civil society and rich public debate, active grassroots movements and free and diverse media. Despite its small size in terms of population, Norway has eight political parties represented in the current Storting (the national parliament), more than 200 newspapers, over 400 municipalities and a highly active and diverse civil society (MedieNorge 2016; Salamon et al. 2013). The resultant multitude of voices and views serve to check and balance each other, ensuring the selection over time of good ideas and practices and allowing the public to challenge and expose poor practices (see also Berrefjord and Heum 1990, 34).

The book assesses this hypothesis through case studies of the main oiland gas- producing countries around the world. However, I also want to check the hypothesis against the Norwegian case out of which it grew. That is the purpose of this chapter, and its research question is thus: Have civil society and public debate played a decisive role in the development of petroleum governance in Norway? 
Although it touches on many issues that have arisen in the Norwegian petroleum sector, this chapter is not an attempt at a comprehensive history of the sector. It focuses on the developments and episodes relevant to the research question. In particular, it deals with the earliest and latest phases of the development of the sector-in order to compare the system in two quite different eras, encompassing the outer timepoints the Norwegian petroleum era. The chapter starts with three sections on different periods and then goes on to examine more closely the sovereign wealth fund and environmental issues. For definitions of the terminology used in the chapter, see the book's introduction.

\section{0s and 1970s: Early Days}

Accounts of the start of oil and gas extraction in Norway dwell on the role of international oil companies, negotiations on the delimitation of the North Sea maritime boundary, access to technology and the interaction between key actors in the ministries. Civil society and the broader public seem to have played a limited role (Berrefjord and Heum 1990, 30), and even the Prime Minister and the Storting were initially not heavily involved (Naustdalslid 1975, 21). A major published work in this field, Volume I of Norsk oljehistorie [Norwegian Oil History], is 523 pages long, but the section on public debate takes up a mere two pages and mentions only the Confederation of Industry and a conference of economists (Hanisch and Nerheim 1992, 417-418). According to the standard Norwegian encyclopaedia, '...there was no public debate about the early phase of Norwegian oil policy' (Store norske leksikon 2016).

A 1971 White Paper spelled out the 'Ten Oil Commandments', which came to guide Norwegian petroleum policy for many years (Stortingets industrikomité 1971, 638). However, none of the commandments concerned the involvement of broader segments of society in policy formulation: it was assumed that the state would take care of things.

Thus, the first decade or so of Norwegian oil revolved around a small number of high-level political operators (Naustdalslid 1975, 32-33; 
Ryggvik 2009, 75). During this period, the lawyer and politician Jens Evensen played a central and celebrated role (Meland and Johannesen 2014, 7). Evensen had been a resistance fighter during the Second World War and had served as prosecutor in the post-war trials against Nazi collaborators. When the first permits to carry out exploration were allocated to international oil companies, very few people, including politicians, received enough information to have much of an opinion on the matter, and Evensen worked to make sure that the process proceeded as smoothly as possible and without disruptive public debate (Ryggvik 2009, 67, 71). The licensing system established during that period came to constitute the backbone of Norwegian petroleum sector management for several decades (Berrefjord and Heum 1990, 30).

The Labour government of Trygve Bratteli held power only for the brief period from March 1971 to September 1972_-but managed to play a pivotal role in the development of the country's petroleum industry. Bratteli's Minister of Industry, Finn Lied, was closely connected with the industrial powerbroker Jens C. Hauge, who had a background as an undercover resistance fighter during the Second World War and as Minister of Defence after the war (Ryggvik 2009, 81). Lied also brought in the economist Arve Johnsen as State Secretary. Lied, Hauge and Johnsen worked energetically for the creation of a large national oil company-Statoil_facing off the Conservatives in opposition, who feared that private business would be squeezed out (Lerøen 2014). ${ }^{1}$ The ministerial and parliamentary policy documents needed for establishing Statoil were urgently produced during the Bratteli government's brief tenure (Ryggvik 2009, 86).

Only four days after the Bratteli government resigned, Hauge became the first Chairman of the Board of Statoil, and soon afterwards, Johnsen was appointed the company's first director. When Hauge stepped down as Chairman in 1974, Lied took over and held the position for the next 10 years (Store norske leksikon 2016).

In most countries, such developments might have been interpreted as tell-tale signs of a nepotistic and corrupt system. As Ryggvik (2009, 85) puts it, there was 'no other way of getting closer to the honey pot'. Some aspects of the development bear a superficial resemblance to the case of Vladimir Putin, Igor Sechin and Rosneft in Russia: people with 
secret service and military connections worked hard to secure a government-controlled national oil company using left-wing arguments about national interest and subsequently shifted seamlessly between posts in government and positions in the company. In the Norwegian case, however, Statoil became a relatively efficient, commercially successful company that largely served the interests of the Norwegian populace (Austvik 2012; Thurber et al. 2011; Thurber and Istad 2012; Eller et al. 2007, 3).

When Prime Minister Trygve Bratteli in 1972 proposed establishing new institutions to manage the petroleum sector, he stated that it would be desirable for the national oil company and the governmental oil directorate to be 'physically integrated', for example, in the form of shared office facilities (Bratteli cited in Hagland 1983, 47). This indicated a failure to separate the institutions of petroleum governance, something that has led to problems in many an oil-producing country (McPherson 2003, 190; Luong and Weinthal 2010, 11; Tordo et al. 2011; Wainberg and Foss 2007).

However, again the Norwegian experience diverges from that of many other countries. Over time, the Norwegian government institutions governing the petroleum sector evolved towards greater transparency and accountability. Already in the 1974 White Paper No 25, it was stressed that democratic institutions should maintain control over the petroleum sector (Ministry of Finance 1974). In 1978, the government decided that the Resource Division of the Petroleum Directorate was to report to the newly created Ministry of Oil and Energy, whereas the Directorate's Safety Division would be under the Ministry of Local Government and Labour Affairs. The State Pollution Control Authority retained responsibility for oil spills and reported to the Ministry of the Environment. According to Ryggvik $(2011,71)$, the division of labour and power between these institutions was crucial in ensuring checks and balances and created more openings for public engagement with a system that might otherwise have become a closed circuit (see also Ryggvik 2009, 97).

Checks and balances were created at multiple levels within government and between government and the private sector: between the Storting and government, between multiple state institutions in the 
petroleum sector, between state institutions and the national oil company, between the national oil company and private and international oil companies (Berrefjord and Heum 1990, 31, 35; Wyller 1975, 156). Despite the narrow beginning, the Norwegian institutions ultimately came to be seen as the 'canonical model of good bureaucratic design for a hydrocarbon sector' (Thurber and Istad 2012, 599).

However, according to Håkon Lavik $(1999,78)$, who worked as a journalist between 1970 and 1974 for Norway's major quality daily, Aftenposten, there was little serious media coverage of the North Sea oilfields until around 1977-1978 (see also Ryggvik 2009, 180). The increase in media interest was triggered by a rise in trade union activity in the petroleum sector. There had been numerous fatal accidents in connection with the construction and operation of the first Norwegian oil platforms and a serious blow-out at the Ekofisk Bravo platform in 1977. In 1978, the unions launched a series of strikes aimed at improving working conditions and pay for oil workers. The strikes went on sporadically until 1986, peaking around 1981 (Ryggvik 2011). Thus, the trade unions were one of the first elements of Norwegian civil society that sought to influence the petroleum sector and to place it firmly on the public agenda. As noted by Berrefjord and Heum (1990, 36), 'Norwegian oil policy was no longer a matter to be left to a few people to define'.

\section{0s and 1990s: Norwegian Oil Reaches Maturity}

Even before Statoil was established, there were concerns that the economic and political power that such a company could amass would enable it to control political processes in the country rather than vice versa (Ryggvik 2009, 189; Berrefjord and Heum 1990, 34, 39). People on the right of the political spectrum feared that a powerful, state-owned Statoil would move Norway towards a centrally planned economy; people on the left feared that Statoil could undermine Norwegian democracy. 
When the large Statford oil and gas field started generating substantial revenue for Statoil around 1980, the company's clout grew substantially, deepening fears about its dominant position in society (Ryggvik 2009, 189). After protracted debate, the parties in the Storting reached a compromise in 1984, whereby a large portion of Statoil's assets would be spun off into a separate economic entity referred to as the State's Direct Financial Interest (SDFI) [Statens direkte økonomiske engasjement]. Over time, the value of SDFI became significantly greater than that of Statoil. This limited Statoil's dominant position in the petroleum sector and in Norwegian society, without disrupting the high degree of government control over petroleum revenues. Statoil went on to become a major centre of power in Norwegian society, but would probably have become even more of a behemoth had it not been for SDFI (Ryggvik 2009, 190).

In 1986, the three main companies on the Norwegian continental shelf were forced into the Gas Negotiating Committee [Gassforhandlingsutvalget] established to negotiate the sale of all Norwegian gas collectively. Part of the logic behind the creation of this new institution was to limit the dominance of Statoil while ensuring continued Norwegian control (Austvik 2012, 322).

In 1988, a major scandal erupted in connection with Statoil's construction of an oil refinery at Mongstad on the west coast of Norway. Steadily worsening cost overruns ended up at NOK 6 billion (ca. USD 900 million), a sum that caused a public uproar (Austvik 2007, 210). The matter received intensive media coverage; the Statoil board was disbanded, and Arve Johnsen, who was still CEO, had to step down in disgrace. The term 'mong' was coined, meaning a sum of money equivalent to the Mongstad cost overrun, and was used many years afterwards to ironize over wastage in Norway's nouveau riche, oil-fuelled economy (e.g. Fadnes 2007). Philosopher and novelist Georg Johannesen (under the pseudonym Guri Johns) wrote a satirical novel about Mongstad in which an armada of helicopters thundered over his head on their way to the refinery's central canteen (Johns 1989). Clearly, at this point, there was no lack of public debate.

However, the next major development caused relatively little public discussion: in 1990, Statoil entered a strategic alliance with BP. The two 
companies were to work closely together in China, the Soviet Union, Vietnam and West Africa. This signalled a major shift-from Statoil as the key instrument for securing Norway's national interest on its continental shelf against powerful international oil companies, to a striving to become one of those companies. Ryggvik $(2009,207)$ refers to the deal as 'dramatically comprehensive' and notes that the financially weak BP was mainly interested in Statoil's considerable cash reserves. Statoil's CEO Harald Norvik had little trouble mobilizing the support of the politicians, officials and journalists who surrounded him. According to Ryggvik (2009, 195), reactions to Norvik's vision in a meeting at the Polytechnic Society in the spring of 1990 were 'enthusiastic, almost euphoric'.

\section{0s: Privatization of Statoil}

On 18 June 2001, Statoil was partially privatized and listed on the Oslo Stock Exchange. Early on in the preceding debate on privatization, only the Conservative Party and the Progress Party had been clearly in favour. The Socialist Left Party opposed any form or degree of privatization, while the parties at the centre of the political spectrum (the Centre, Christian Democrat and Liberal parties) did not initially have a clear position on the matter. The two unions of oil workers held differing views, and Labour was divided on this question (Ryggvik 2010, 104). As the country's largest political party, the Labour Party's conclusions would be decisive for the outcome.

Jens Stoltenberg, Labour Party leader and Prime Minister in 2000-2001 was among those who saw that, if it remained fully state-owned, Statoil would likely never be as efficient as a private company could be. Government-owned oil companies in many countries were highly inefficient, and it was hoped that partial privatization could help Statoil to avoid such a fate. The Labour Party voted at its annual congress in November 2000 to support partial privatization, and later that year the Labour government presented the privatization proposal to the Storting. A significant minority within the party, however, wanted the company to remain fully state-owned. Reflecting the level of political conflict caused by the partial privatization of Statoil, Finn Lied in 2008 called it 'one of 
greatest errors in Norwegian political history' (Lied cited in Haugstad 2008, 30).

The process that led to Statoil's partial privatization in 2001 had been kicked off by the then-director of Statoil, Harald Norvik, who launched a public debate about the matter in 1999, after pondering it for 10 years (Ask 2002; Hellestøl 1999; Ryggvik 2010). Olav Fjell, who took over as CEO of Statoil after Harald Norvik in 1999, continued the pressure for partial privatization of the company. 'A $30 \%$ privatization may result in huge money. Huge money', he told a Norwegian journalist in November 1999 (Fjell cited in Lorentzen 1999).

The public debate on whether to privatize or not peaked in 2000. A search for the words 'Statoil AND partial privatization' ['Statoil AND delprivatisering'] in the Norwegian newspaper archive Atekst yields only 20 hits for 1998, but 217 for 1999 and 525 for 2000. Articles include interviews with Statoil managers and politicians, op-eds, editorials and guest commentaries by economists and others. These articles played a central role in raising the issue of privatization, paving the way for it to be carried through.

In addition, within the Labour Party there was a network that was not publicly known, the so-called oil group, and its discreet promotion of privatization may have been decisive. A former editor of the social democratic daily Arbeiderbladet, Wiktor Martinsen (2004), has argued that privatization would probably not have taken place if the existence of the oil group had been publicly known in 2000. In his book Statoil for Sale, he strongly criticizes Labour Party leader Jens Stoltenberg and others in the party leadership for having let down the labour movement by moving forward on privatization without a broader discussion within the party (Martinsen 2004). In an interview with the newspaper Aftenposten, Martinsen said:

They were obsessed by a new idea, and the partial privatization of Statoil represented a totally different policy than the party had previously represented. Therefore, this issue should have been subject to a broad debate within the party, but this did not happen. At first, many of them didn't even want the party's national congress to consider this important matter. (Martinsen cited in Salvesen 2004) 
After the initial partial privatization of Statoil in 2001, the state's share of the company was $81.7 \%$. Following further sale of stock in 2004 and 2005 , the government share fell to $70.9 \%$. Meanwhile, the debate continued. In 2005, left-wing academics Helge Ryggvik and Ole Andreas Engen $(2005,56)$, in cooperation with the SAFE union of oil workers, issued a report proposing an alternative petroleum policy, arguing that the state should fully renationalize the company.

In 2007, when Statoil merged with the oil and gas division of its rival Norsk Hydro, which had a majority of private shareholders, the state share of the new company fell to $62.5 \%$. However, in subsequent years the government bought back shares to raise its stake to $67 \%$ again. Although this was not what Ryggvik and Engen had envisaged, the partial privatization of Statoil and, later, the retention of an absolute majority of the shares by the government represents a typical Nordic compromise between state and private ownership, each of which is championed by different political parties and interest groups (see also Berrefjord and Heum 1990, 46).

\section{The Sovereign Wealth Fund}

The oil price hikes in the 1970 s made it clear that the flow of petroleum revenues was determined by exogenous factors that could be neither controlled nor predicted. A consultative committee, led by the Director of the Central Bank, Harald Skånland, was appointed to come up with suggestions for how to handle such fluctuations. The committee proposed that the state's petroleum revenues should be decoupled from its budget expenditure by saving the revenues in a fund. It also proposed that the fund should be placed in international capital markets to avoid overheating of the Norwegian economy (Lie 2012, 151). This fund was finally established in 1990 (Steigum 2002, 7).

The creation of the sovereign wealth fund was also associated with the departure from the policy of limiting the expansion of oil and gas extraction. This had been a central element of Norwegian petroleum policy and policy debates in the first half of the 1970s but had gradually faded 
(Ministry of Finance 1974, 6; Kristoffersen 2014, 20; Bergesen 1975, 52). The first departures from the policy of limiting the growth of oil and gas extraction were counter-cyclical economic measures taken during periods of economic crisis (Ryggvik 2009, 150). As the petroleum sector and its clout grew, vested interests within the sector started pushing harder for expansion. When the financial spokesperson for the Conservatives, Per Kristian Foss, proposed that petroleum development should be slowed down, he was met by a 'storm of protest' from the oil companies (Ryggvik 2009, 194). The creation of the sovereign wealth fund marked the death knell for self-imposed limitations on oil and gas development: it could now be argued that there was no need to limit the pace of oil and gas extraction, because any surplus created could be placed in financial assets abroad-earning more interest than resources in the ground while avoiding overheating of the Norwegian economy.

\section{Spending the Proceeds}

Entertainingly, many Norwegians refer to the sovereign wealth fund in English as 'the fun', presumably due to problems with English pronunciation, as the final ' $\mathrm{d}$ ' is often silent in the equivalent Norwegian word, fond. Over the years, most actors came to see the fund as a good thing, nonetheless many aspects of fund management continued to be debated and adjusted (see Langved 2014; Linderud and Langved 2015; Haram and Senel 2015).

In 2001, the Labour government of Jens Stoltenberg introduced the 'fiscal rule', according to which a maximum of $4 \%$ of the fund's value-equivalent to the expected annual capital gains after inflation-could be spent per year (Holden 2013, 871). The right-wing Progress Party opposed this and stated explicitly in its party programme that the fiscal rule should be slackened: 'The Progress Party has always believed that the petroleum fund, which is overflowing with money, should be used for investments in Norway to ensure that we have good hospitals, homes for the elderly, schools and infrastructure for future generations' (FRP 2016). Also members of other political parties have argued that the money should be invested in Norway 
rather than in international financial markets. 'Spend the money on schools, medical care and roads', an MP from the pro-agrarian Centre Party said in 2002, criticizing his own party for failing to secure sufficient funds for rural parts of the country (Kopland 2002).

Trying to rein in the urge to spend the country's wealth, the Governor of the Central Bank proposed in 2012 that the limit set out by the fiscal rule be reduced from $4 \%$ to $3 \%$ (Olsen 2012, 7). Also other Norwegian experts - such as former Director of Statistics Norway, Hans Henrik Scheel and Professors Hilde Bjørnland and Steinar Holden-argued for stricter curbs on spending (Haug 2014).

Humphreys and Sandbu $(2007,195,216)$ state that the limitations on what Norway's sovereign wealth fund can do are actually 'extremely weak', that the fiscal rule is in fact an informal convention rather than written law and that it is mainly the broader societal context that limits the actions of policymakers and fund managers. They believe that, in a different context, the fund would be unlikely to function as successfully (see also Stevens and Dietsche 2008, 60).

\section{Where to Invest?}

Initially, the fund was invested exclusively in foreign government bonds, but in 1997 the Storting voted to place 40\% of the fund's capital in foreign stocks. In 2007, the Ministry of Finance decided to increase the ratio of stocks from $40 \%$ to $60 \%$ (NBIM).

Many different actors contributed to discussions about the allocation of the fund's capital. Arne Jon Isachsen, a professor at the Norwegian Business School, has been active in the debate about the petroleum fund's investments by appearing in the media, blogging and participating in public seminars. For example, in 2004 he recommended that the fund invest in real estate in addition to stocks and bonds, arguing that it would bring diversification while helping to prevent the fund from becoming too influential on the world's stock markets (Isachsen 2004, 3). The Norwegian government decided in 2010 that up to $5 \%$ of the fund should be invested in real estate.

Investor and billionaire Øystein Stray Spetalen has on many occasions harshly criticized the management of the petroleum fund. Particularly 
critical about the use of foreign companies to handle fund investments, he has branded the fund's investment strategy a 'total failure' (Spetalen cited in E24 2011), and its stock market investments 'madness' (cited in Nervik and Haugan 2011). It is not clear whether Spetalen has had much influence, but he is one of the many different people involved in the public debate on how to handle Norway's petroleum wealth.

\section{Ethical Guidelines for Fund Investments}

In 2001, a Human Rights Council was established by the Ministry of Finance to help the fund avoid getting involved in human rights violations through its investments (Etikkrådet 2015). However, some actors wanted a stronger structure to ensure ethical investment of the fund's vast holdings, with clearly defined guidelines and a Council on Ethics with a broader scope than the Human Rights Council. These were ultimately created in 2004, after considerable public debate (RORG 2015).

At first, almost all politicians and the entire bureaucracy had been against the idea of imposing further ethical requirements, fearing that it would cause the fund to lose money. For example, outspoken author and journalist Erling Fossen (2002) was highly sceptical that a petroleum fund could be an ethical investor. Others, such as a commentator in $V G$, the country's largest newspaper, were more optimistic (Staavi 2015). Yet, civil society continued to push for the creation of a Council on Ethics - and once the council had been established, political players across the board were proud of it. This is thus an example of the successful influence of civil society on Norwegian petroleum revenue management.

A broad range of civil society actors contributed to the public debate that led up to the creation of the ethical guidelines and ethics council. In March 2002, the NGO Framtiden i våre hender [The Future in our Hands] published a report concluding that the fund had invested in companies that damaged the environment and violated human rights (Bay 2002). In June 2002, an expert on international law, Asbjørn Eide, harshly criticized a set of ethical guidelines proposed by the government. 'This is not good enough. Even if the Storting approves the proposal from the government, many of the fund's investments will not 
be in the spirit of international law' (Eide cited in Ergo 2002). Prior to the parliamentary vote on the ethical guidelines, the Norwegian Forum for Development and Environment, a network of 50 Norwegian developmental, environmental, peace and human rights organizations, produced recommendations for the contents of the ethical guidelines (ForUM 2003).

In the end, the government-appointed Graver Commission recommended the creation of a Council on Ethics and a set of ethical guidelines (NOU 2003, 22). The composition of the Graver Commission provides another example of the involvement of relatively diverse actors in Norwegian policy discussions: Hans Petter Graver (Professor, law), Jarle Bergo (Deputy Director of the Bank of Norway), Alexander Cappelen (Associate Professor, economics), Ola Löhman (Swedish consultant), Janne Haaland Matlary (Professor, political science), Gro Nystuen (PhD candidate, law), Bente Rathe (businesswoman), Lasse Ruud (company director), Per Sandberg (engineer) and Anne Kristin Sydnes (Special Advisor and former Minister of Development).

The five members of the Council on Ethics are appointed by the Ministry of Finance. They do their work not as government employees but as individuals with academic expertise, high-level experience from private business or links to civil society (Etikkrådet 2016). The council receives a steady flow of suggestions from NGOs and other organizations concerning specific companies or business areas that should be banned from the fund's holdings. As a result, it functions as a channel for contact with civil society, and the public debate over the council continues, with input from organizations such as Amnesty Norway, Nature and Youth, Bellona, Friends of the Earth Norway and individuals such as business development specialist Terje Osmundsen.

\section{Environmental Policy Issues}

Exemplifying the continuing debate surrounding the sovereign wealth fund are the efforts of the Rainforest Foundation to stop the fund from investing in companies that contribute to the destruction of tropical forests (Regnskogfondet 2014). Also the Church of Norway 
has contributed to the debate, arguing that the overarching goal of the fund must not be to achieve the highest possible returns and encouraging it to prioritize climate change and poverty reduction. 'Faith in ... God makes sustainable management of His creation, compassion and solidarity with future generations, poor and marginalized people, indispensable values for the Church of Norway', the Church wrote in a statement after its 2013 synod. It also had several specific suggestions, for example, that $5 \%$ of the fund should be invested in poor countries, rising to $10 \%$ over time (Den norske kirke 2013). These suggestions have not yet been followed up.

One area of particularly active debate has been whether the fund should invest in coal companies. In 2014, the NGOs Framtiden i våre hender, Greenpeace and Urgewald published a report on the fund's investments in coal. They found that NOK 82 billion was still invested in 156 coal companies, a figure far greater than previously admitted by the fund managers (Linderud 2015; Jorde 2014; Schücking 2014). An expert group led by former high-ranking Ministry of Finance official Martin Skancke in 2014 advised the government not to pull out of all coal companies, arguing that the fund is a more ethical shareholder than most others and that it is easier to influence the companies from within. 'Coal mining in itself is not an ethically reprehensible activity', they held (Skancke cited in Dagbladet 2014). However, the Storting ultimately voted that the fund should withdraw from coalrelated investment, starting from 1 January 2016. Civil society had won again.

Another example of the growing importance of environmental issues in the public debate about petroleum policy concerned whether to start using natural gas to generate electricity, which had previously been generated almost exclusively from hydropower in Norway. In March 2000, after a protracted public debate, the minority government lead by the Christian Democrat Kjell Magne Bondevik stepped down when the opposition parties forced through changes to the legislation on pollution to facilitate the building of gas power plants at Kollsnes and Kårstø in western Norway. The Bondevik government chose to relinquish power rather than retract its climate policy pledges (Balke Hveem 2016). 


\section{Oil Exploration in the Lofoten and Vesterålen Archipelagos}

One of the most controversial petroleum policy issues after the turn of the millennium was whether to carry out an environmental impact assessment of potential petroleum extraction in the seas off the Lofoten and Vesterålen archipelagos in the Arctic part of Norway. This area was expected to hold vast oil and gas resources but is also a spawning ground for some of the world's richest fish stocks and an area of great touristic potential (Overland and Krivorotov 2015). An environmental impact assessment was considered by many as the first step towards oil and gas extraction there.

In 2009, the Popular Campaign for an Oil-Free Lofoten and Vesterålen [Folkeaksjonen oljefritt Lofoten, Vesterålen og Senja] was founded, bringing together several smaller initiatives (Hegnar 2009). In 2010, three of the most active environmental organizations in Norway-Bellona, Friends of the Earth and Nature and Youth-presented a joint statement to the government concerning petroleum activity in Lofoten and Vesterålen, recommending permanent protection (Pedersen 2010).

By contrast, at the time many local politicians were lobbying in favour of oil exploration, eyeing oil-related jobs and business opportunities for their municipalities. In 2011, some 20 mayors from municipalities in the northern counties of Nordland and Troms arrived at the office of Prime Minister Jens Stoltenberg, demanding the expansion of petroleum exploration to their areas (NTB 2011). Despite these efforts, the Stoltenberg government (a coalition of the Labour Party, the Centre Party and the Socialist Left Party) decided to put petroleum activity in Lofoten and Vesterålen on hold. In 2012, 17 mayors, deputy mayors and the district administrator in Nordland and Troms made similar demands as their colleagues had in the previous year. The spokesperson for these politicians told the journalists present: 'We are doing this together because we are eager to have a taste of the good life. We don't want to fall behind and to be put on hold indefinitely. We make this appeal hoping that it will put pressure on the government' (cited in Ree 2012). 
In 2014, a report prepared by the analytical consultancy Rystad Energy and sponsored by the Norwegian Oil Industry Association concluded that opening the maritime areas off the Lofoten and Vesterålen archipelago to petroleum exploration would generate more than 1000 jobs in the region (Rørstad and Thonhaugen 2014). Following the publication of the report, Geir Seljeseth of the Norwegian Oil Industry Association stated: 'In order to extract oil and gas off Lofoten, Vesterålen and Senja, the companies will spend NOK 60 billion annually for a long period of time. This means a lot of jobs and activity...' (cited in Rørstad and Thonhaugen 2014).

The oil companies argued vigorously that opening Lofoten and Vesterålen to the petroleum industry could counteract the expected fall in production from existing fields on the Norwegian continental shelf after 2020. In 2014, one of Statoil's Directors, Arne Sigve Nylund, stated: 'Exploring new areas is important in order to acquire new acreage. It's important because we wish to support long-term development in the north' (Nylund cited in Mogård and Stav 2014).

At the time, the issue had been put on hold by the government until 2017. This represented a compromise between the two governing parties (the Conservatives and the Progress Party, both in favour of launching an assessment of the area for oil exploration) and the two parties in the Storting supporting their minority government (the Liberal Democrats and Christian Democrats, who were opposed to oil development). The local branch of the Progress Party in Northern Norway expressed dissatisfaction with the Party's central leadership because it had compromised with the other parties by agreeing not to open up the area to petroleum exploration (Lysvold 2013).

\section{Conclusions}

According to the standard Norwegian encyclopaedia, "The history [of the Norwegian petroleum sector] is not one of unilineal development characterized by a gradual, harmonic approach to the challenges faced. Even in cases where permanent solutions were found there was often a complicated prehistory characterized by conflicting interests and confrontations' 
(Store norske leksikon 2016; see also Wyller and Wyller 1975, 8). Unravelling the (relative) success story of Norwegian natural resource management is therefore complicated, and civil society involvement and open public debate are not the only important elements of Norwegian petroleum governance. During the early years of the country's oil and gas development, most important choices were made by a small number of decision-makers in government, with scant input from the broader society. This may partly have been because there was little understanding of what was at stake. In a letter to the Foreign Ministry in 1958, the Geological Survey of Norway stated 'One can disregard the possibility that there is coal, oil or sulphur on the continental shelf along the Norwegian coast' (Geological Survey of Norway 1958; see also Naustdalslid 1975, 15). When Phillips Petroleum contacted the Norwegian authorities in 1962 about the possibility of conducting exploration off the Norwegian coast, the prominent Norwegian statesman Trygve Lie replied: 'I think you are mistaken. Norway has no oil or gas' (Lie cited in Helle 1984, 25; see also Berrefjord and Heum 1990, 29).

Especially during the early years, but also later, many factors other than civil society and public debate were decisive for Norwegian petroleum governance. Here we should note the existence of well-functioning political parties, competent and well-intentioned government officials and the separation of powers and division of labour within government and between government and the private sector (Berrefjord and Heum 1990, 32).

The character of government officials seems to have been particularly important. There was relatively little corruption; moreover, officials often took a technocratic view of the petroleum sector, a view supported by academics and other independent experts, ensuring a considerable technocratic element in the evolution of Norwegian petroleum governance (Wyller and Wyller 1975, 8; Naustdalslid 1975, 27). Especially during the two first decades of the Norwegian petroleum era, economists at the Norwegian School of Economics (NHH), Statistics Norway and the University of Oslo played important roles (see Eide 1974; Aarrestad 1978; Bjerkholt et al. 1981; Bjerkholt and Offerdal 1985). The economists at the Ministry of Finance had a particularly strong and independent role (Steigum and Thøgersen 2014, 4), almost in the style of the BBC comedy series Yes Minister. 
Also later on, technocrats continued to play an important role. The decision on partial privatization of Statoil was propelled forward by a small number of people who employed technocratic arguments, not by public discussion and support (although that also took place). The numerous populist initiatives for spending the oil revenues — such as a proposal by Høibraaten (2016) that the sovereign wealth fund be paid out to the citizens in annual instalments of NOK 250,000-were kept at bay by the technocratic forces (see also Moene 2017).

However, some qualification is needed regarding this interpretation of the early days of Norwegian petroleum development as driven by technocratic elites, well-organized government institutions and established political parties without significant interference from society. Firstly, the technocrats were not operating in a vacuum. Norway produces numerous and detailed whitepapers which are easily available, offering an interface between ministerial policy-making and the public. The landmark whitepaper from 1971 containing the 'Ten Oil Commandments' was later followed by many other official documents detailing and discussing government petroleum policy (Stortingets industrikomité 1971, 638; Austvik 2012, 321). By the mid-1970s, the technocrats found themselves facing significant public resistance and debate dealing explicitly and critically with their role (see e.g. Wyller 1975, 172).

Secondly, in the Norwegian context, the distinction between political parties and the broader civil society is blurred. The country has a highly diversified (or fragmented, depending how one sees it) party system, with eight parties currently represented in the Storting and others waiting in the wings - and that with a population of only five million (Tranøy and Østerud 2001, 334). Many of the parties are also affiliated with other sections of civil society-trade unions, business associations, environmental organizations, farmers, the Church and so on. Accordingly, Norway's political parties represent various interest groups, and parliamentary debate fulfils some of the functions of a broader civil society (Ellefsen 1978, 53).

Thirdly, a key aspect of the Norwegian — and Nordic—model is constant compromise. Again, the partial privatization of Statoil serves as an example: those who were against privatization did not get it their way, but neither did those who would have preferred greater privatization and 
more companies competing against each other on the Norwegian continental shelf. The Norwegian state retained an absolute majority of the company's shares, while Statoil also gained a significant minority of private shareholders.

Finally, it did not take long for debate to kick in. By the mid-1970s, there were highly informed discussions among experts about what the petroleum revenue should be used for, how it might change the country, how it should be managed, the risk of the national oil company becoming too strong and so on. For example, Bergesen $(1975,51)$ wrote: 'The question is which problems we can solve through greater government income [from oil], and which we cannot buy our way out of no matter how much money we have'. And 'When the oil extraction comes to an end some day, we will encounter a new difficult transition. How shall we handle this decline? And not least, how long should the oil age last?' (Bergesen 1975, 52). Even before petroleum revenue had much impact on Norwegian society, there was discussion of how to deal with the future decline in revenues.

The awareness of the political dimension of the petroleum sector extended to explicit calls for political debate and for diversity among those appointed to government committees (Wyller 1973, 29, back cover). It was reflected in academic and political publications discussing the political dimension of the development of the petroleum sector, often in the form of edited volumes with many contributors. Some of these appeared early on (e.g. Brotnov 1975), others later (e.g. Olsen 1989). The wave of industrial action among oil workers from 1978 onwards brought these issues to the attention of the broader public.

In an analysis published in the mid-1970s, Hofseth (1975, 42-43) provides an overview of societal actors relevant for the petroleum sector. These were as follows: Statoil, other oil companies, the supply industry, non-petroleum-related industry, service industry, parliament and government, public financial and administrative bodies, public social administrative bodies, coastal municipalities, inland municipalities, workers, fishers, farmers, environmental NGOs, groups concerned with solidarity with developing countries, public energy bodies and taxpayers (italics added). Today that list might look different, but the point is that already at that early stage, before many of these groups had really become engaged in any public debate of petroleum policy, people were thinking and writing 
about the plurality of interests and voices. This also illustrates another important aspect of the Norwegian system: its capacity to anticipate and prepare for issues before they arise.

The answer to the question posed at the beginning of this chapter is therefore that civil society and public debate did play a decisive role in the development of petroleum governance in Norway. However, they were not the only factors involved. The Norwegian experience is characterized by having many legs to stand on, including strong technocratic elements, the parliamentary multi-party system, a culture of compromise and of looking forward.

Skredderberget (2015) argues that the most important lesson to be learned from Norway is that it is important to be lucky (see also Ryggvik 2009, 64). Three examples can serve as illustrations of this luck. First, the Ekofisk oilfield, the discovery of which launched the Norwegian petroleum boom in 1969, is located near the maritime boundary between Denmark and Norway and might have ended up being Danish (Hanisch and Nerheim $1992,47,50)$. Second, the decision to change the sovereign wealth fund's ratio of stocks to bonds from 40/60 to 60/40 seemed to be driven by rising stock values - a typical greedy-investor error. However, it took time for the government apparatus to implement this change — and by the time it did, it so happened that stocks had fallen significantly. In trying to implement a bad idea, Norway got lucky and ended up buying cheap stocks and making a lot of money. Third, the behaviour and roles of key actors in the early phase of Norwegian petroleum development-for example, Finn Lied, Jens C. Hauge and Arve Johnsen — seemed dubious, but they established a petroleum governance system that performed well for decades.

Amid the self-congratulatory backslapping over the success of Norway's management of its natural resource wealth (Ryggvik 2009, 13-14; Moene 2017), it is important to remember that such strokes of luck are an important part of the story. But we should also note that other aspects of Norway's luck included having in place, before the oil deluge, a lively civil society, an unfettered public debate, diverse media outlets, a competent and technocratically oriented bureaucracy and low levels of corruption and conflict. All those factors are related to structural aspects of society, making them difficult but not impossible for other countries to achieve. 
Acknowledgements Special thanks go to Jens Andvig, Ole Gunnar Austvik, Solveig Avelsgaard Lien, Susan Høivik, Berit Kristoffersen, Aril Moe and Emma Wilson for inputs to this chapter. It has also been inspired by those who contributed lectures to the seminar series out of which this book grew, as well as the institutions that hosted visits in connection with the seminars: Cecilie Hellestveit, Arne Jon Isachsen, Einar Lie, Norwegian Bank Investment Management, the Norwegian Ministry of Petroleum and Energy, Hilde-Marit Rysst, Martin Skancke and Asle Skrederberget. I am deeply grateful to the Norwegian Ministry of Foreign Affairs, for financing the project out of which this book grew, as well as to the RusChange project financed by the Research Council of Norway for additional support. Needless to say, I remain responsible for this chapter and its content. All translations from Norwegian to English were done by me.

\section{Notes}

1. For a discussion of what constitutes a national oil company, see Victor et al. $(2012,4)$.

\section{References}

Aarrestad, J. 1978. Optimal Saving and Exhaustible Resource Extraction in an Open Economy. Journal of Economic Theory 19: 163-179.

Ask, Alf Ole. 2002. Privatisering stanset i 1992. Aftenposten. Accessed on 16 September 2002.

Austvik, Ole Gunnar. 2007. Staten som petroleumsentreprenør. Tidsskrift for samfunnsforskning 48 (2): 197-226.

- 2012. Landlord and Entrepreneur: The Shifting Roles of the State in Norwegian Oil and Gas Policy. Governance 25 (2): 315-334.

Balke Hveem, Ellen. 2016. Det norske oljeeventyret: 50 år med milliardinntekter, tapte liv og politisk krangel. Aftenposten. http://www.aftenposten.no/ okonomi/Det-norske-oljeeventyret-50-ar-med-milliardinntekter_-tapte-livog-politisk-krangel-600471b.html. Accessed on 3 August 2016.

Bay, Ingrid. 2002. Verdiløse penger? Oljefondet-Veien mot etiske retningslinjer. Fremtiden $i$ våre hender/Forskningsinstitutt FIFI 1/2002. http://www. framtiden.no/rapporter/rapporter-2002/68-verdilose-penger-1-02/file.html. Accessed on 8 May 2015. 
Bergesen, Helge Ole. 1975. Uttappingstempoet-Oljepolitikkens nøkkelbegrep. In Norsk oljepolitikk, ed. Kari Bruun Wyller and Thomas Christian Wyller, 51-71. Oslo: Gyldendal.

Berrefjord, Ole, and Per Heum. 1990. Political Governance of the Petroleum Industry: The Norwegian Case. In Naive Newcomer or Shrewd Salesman? Norway-A Major Oil and Gas Exporter, ed. Helge Ole Bergesen and Anne Kristin Sydnes, 28-48. Oslo: Fridtjof Nansen Institute.

Bjerkholt, O., L. Lorentsen, and S. Strøm. 1981. Using the Oil and Gas Revenues: The Norwegian Case. In Oil or Industry, ed. T. Barker and V. Brailovsky, 171-184. London: Academic Press.

Bjerkholt, O., and E. Offerdal, eds. 1985. Macroeconomic Prospects for a Small Oil-Exporting Economy. Dortrecht: Martinus Nijhoff.

Brotnov, Jan, ed. 1975. Oljen i samfunnsmaskineriet: De norske oljemilliardenes innvirkning bl.a. på samfunnsøkonomien naringsliv, bosetting, familien, folkevalgt styring og internasjonal politikkk. Oslo: Cultura forlag.

Dagbladet. 2014. Oljefondet ut av kull. Dagbladet. http://www.dagbladet. no/2014/12/05/kultur/meninger/leder1/dbmener/oljefondet/36582153/. Accessed on 12 May 2017.

Den norske kirke. 2013. Etisk forvaltning av statens pensjonsfond utland. https://www.regjeringen.no/contentassets/c0523b1aa5f943e89f1c6d830cb3cf68/kirke.pdf. Accessed on 11 May 2015.

E24. 2011. - Dette er en varslet katastrofe. http://e24.no/makro-og-politikk/ spetalen-angriper-oljefondet-igjen-dette-er-en-varslet-katastrofe/20088514. Accessed on 10 February 2017.

Eide, Erling. 1974. Virkninger av statens oljeinntekter på norsk økonomi. Sosialøkonomen 10: 12-21.

Ellefsen, Vegard. 1978. Ilandforing av petroleum sør for $62^{\circ} \mathrm{N}$ : En analyse av norsk ilandforingspolitikk fra Ekofisk til Statfjord. M.Phil. (hovedfag) thesis, Institute of Political Science, University of Oslo.

Eller, Stacy, Peter Hartley, and Kenneth Medlock. 2007. Empirical Evidence of the Operational Efficiency of National Oil Companies. Houston, TX: James A. Baker III Institute for Public Policy.

Ergo, Thomas. 2002. Slakter Bondeviks oljefondforslag. Dagbladet. http://www. dagbladet.no/nyheter/2002/06/12/337419.html. Accessed on 8 May 2015.

Etikkrådet. 2015. Tidslinje. http://etikkradet.no/historikk/tidslinje/. Accessed on 8 May 2015.

. 2016. Rådsmedlemmer. http://etikkradet.no/radsmedlemmer/. Accessed on 12 April 2016. 
Fadnes, Ole-Morten. 2007. En bortkastet, halv Mong. http://www.dn.no/ meninger/kommentarer/2007/01/03/en-bortkastet-halv-mong. Accessed on 13 March 2017.

ForUM. 2003. Oljefondet: Etiske retningslinjer for statens petroleumsfond. http://www.rorg.no/Artikler/284.html. Accessed on 8 May 2015.

Fossen, Erling. 2002. Mer eller mindre etikk takk? Morgenbladet. http://morgenbladet.no/2002/mer_eller_mindre_etikk_takk\#.VUyphxr2qp5. Accessed on 9 April 2016.

FrP. 2016. Økonomi og samferdsel. https://www.frp.no/hva-vi-mener/okonomi-og-samferdsel. Accessed on 11 December 2016.

Geological Survey of Norway. 1958. FN-konferanse i Geneve 24. februar 1958 om havets folkerett. Letter to the Ministry of Foreign Affairs of Norway, 24 February. http://www.geo365.no/oljehistorie/et-mye-omtalt-brev/. Accessed on 10 April 2016.

Hagland. 1983. Oljedirektoratet 1973-1983. Oslo: Oljedirektoratet.

Hanisch, Tore Jorgen, and Gunnar Nerheim. 1992. Fra vantro til overmot? Norsk oljehistorie. Oslo: Leseselskapet.

Haram, Ingrid Vestre, and Emrah Senel. 2015. - Oljefondet låner penger til land Norge boikotter. http://www.nrk.no/norge/_-oljefondet-laner-pengertil-land-norge-boikotter-1.12345768. Accessed on 23 December 2016.

Haug, Anne Kari. 2014. Advarer mot handlingsregelen. Dagens neringsliv. http:// www.dn.no/nyheter/politikkSamfunn/2014/08/27/2156/Handlingsregelen/ advarer-mot-handlingsregelen. Accessed on 27 August 2014.

Haugstad, Tormod. 2008. Finn Lied (92):-Privatisering av Statoil er en av historiens største tabber. Teknisk Ukeblad 155 (35): 30-35.

Hegnar Online. 2009. Ny folkeaksjon for oljefritt Lofoten og Vesterålen. http// www.hegnar.no/bors/energi/artikkel383862.ece. Accessed on 3 August 2015. Helle, Egil. 1984. Norges olje-De forste 20 arrene. Oslo: Tiden norsk forlag. Hellestøl, Yngve. 1999. Vil ha et nytt olje-Norge. Aftenposten, 22 January.

Hofseth, Paul. 1975. Verdipremissene. In Norsk oljepolitikk, ed. Kari Bruun Wyller and Thomas Christian Wyller, 38-50. Oslo: Gyldendal.

Høibraaten, Kjell. 2016. Én million ekstra til alle. Ytring. https://www.nrk.no/ ytring/en-million-ekstra-til-alle-1.13134395. Accessed on 9 November 2016.

Holden, Steinar. 2013. Avoiding the Resource Curse the Case Norway [sic]. Energy Policy 63: 870-876.

Humphreys, Macartan, and Martin Sandbu. 2007. The Political Economy of Natural Resource Funds. In Escaping the Resource Curse, ed. Macartan 
Humphreys, Jeffrey Sachs, and Joseph Stiglitz, 194-233. New York: Columbia University Press.

Isachsen, Arne Jon. 2004. Noen betraktninger om oljefondet. Working Paper 4/14, Centre for Monetary Economics, BI Norwegian Business School. http:// www.bi.edu/cmeFiles/pdf/wp_14_4.pdf. Accessed on 20 December 2016. Johns, Guri [=Georg Johannesen]. 1989. Romanen om Mongstad. Oslo: Cappelen.

Jorde, Sigurd. 2014. Rapport: Oljefondet er skitnere enn du trodde. http:// www.framtiden.no/201411246611/aktuelt/etiske-investeringer/oljefondeter-skitnere-enn-du-trodde.html. Accessed on 12 May 2015.

Kopland, Kirsten. 2002. - Bruk oljepengene på skole, helse og veier. Kommunal Rapport. http://kommunal-rapport.no/artikkel/bruk_oljepengene_pa_skole_ helse_og_veier. Accessed on 11 May 2015.

Kristoffersen, Berit. 2014. Drilling Oil into Arctic Minds? State Security, Industry Consensus and Local Contestation. PhD Thesis, Faculty of Humanities, Social Science and Education, University of Tromsø.

Langved, Åshild. 2014. Advarer mot økt risiko i Oljefondet. Dagens Naringsliv. http://www.dn.no/nyheter/okonomi/2014/09/22/0857/Oljefondet/advarermot-kt-risiko-i-oljefondet. Accessed on 23 December 2016.

Lavik, Håkon. 1999. Statfjordsaken. In Norsk oljemuseums årbok 1999, ed. oljemuseum Norsk, 70-76. Stavanger: Norsk oljemuseum.

Lerøen, Bjørn Vidar. 2014. Oljens og fellesskapets mann-Arve Johnsen. Stavanger Aftenblad, 14 February, p. 23.

Lie, Einar. 2012. Norsk økonomisk politikk etter 1905. Oslo: Universitetsforlaget. Linderud, Espen. 2015. Utelukker ikke salg av kull. Dagens Naringsliv. https:// www.dn.no/nyheter/finans/2015/02/11/2158/Oljefondet/utelukker-ikkesalg-av-kull. Accessed on 10 February 2017.

Linderud, Espen, and Åshild Langved. 2015. Slyngstad gir nye tall. Dagens Neringsliv. http://www.dn.no/nyheter/2015/05/04/1048/Oljefondet/slyngstad-gir-nye-tall. Accessed on 23 December 2016.

Lorentzen, Torgeir. 1999. Statoil-sjef lokker med milliarder. Dagbladet, 10 November, p. 15.

Luong, Pauline Jones, and Erika Weinthal. 2010. Oil Is Not a Curse: Ownership Structure and Institutions in Post-Soviet Successor States. Cambridge: Cambridge University Press.

Lysvold, Susanne. 2013. Frp i nord skuffet over Lofoten-fredning. NRK. http:// www.nrk.no/nordland/frp-skuffet-over-lofoten-fredning-1.11271767. Accessed on 12 May 2015.

Martinsen, Wiktor. 2004. Statoil til salgs. Oslo: Kolofon. 
McPherson, Charles. 2003. National Oil Companies: Evolution, Issues, Outlook. In Fiscal Policy Formulation and Implementation in Oil-Producing Countries, ed. J.M. Davis, R. Ossowski, and A. Fedelino, 184-203. Washington DC: IMF.

Medie-Norge. 2016. Antall aviser og samlet opplag. http://www.medienorge. uib.no/statistikk/medium/avis/361. Accessed on 10 April 2016.

Meland, Trude, and Geir Mossige Johannesen. 2014. Jubileum og fornying. In Norsk oljemuseums årbok 2014, ed. Oljemuseum Norsk, 7-17. Stavanger: Norsk oljemuseum.

Ministry of Finance. 1974. Petroleumsvirksomhetens plass $i$ det norske samfunn. White Paper No. 25. (St. Meld. nr. 25 (1973-74)).

Moene, Kalle. 2017. Ni seire av ti mulige. Dagens naringsliv. http://www.dn.no/ meninger/2017/03/31/2047/Med-egne-ord/ni-seire-av-ti-mulige. Accessed on April 2017.

Mogård, Lars Egil, and Torill Ustad Stav. 2014. Ønsker fremdeles konsekvensutredning for LoVeSe. NRK. http://www.nrk.no/troms/onsker-enna-konsek vensutredning-1.11884868. Accessed on 12 May 2014.

Naustdalslid, Jon. 1975. Oljesaka i statlege komitear og utval. In Norsk oljepolitikk, ed. Kari Bruun Wyller and Thomas Christian Wyller, 11-37. Oslo: Gyldendal.

NBIM. 2016. Historien. http://www.nbim.no/fondet/historien/. Accessed on 9 December 2016.

2017. Oljefondets markedsverdi. http://www.nbim.no/no/. Accessed on 10 April 2016.

Nervik, Stein, and Bjørn Haugan. 2011. Spetalen: - Oljefondets gambling må stanses. http://e24.no/makro-og-politikk/spetalen-oljefondets-gamblingmaa-stanses/20115075. Accessed on 10 February 2017.

NOU. 2003. Forvaltning for fremtiden. Forslag til etiske retningslinjer for statens petroleumsfond. NOU 22. http://etikkradet.no/files/2015/01/Graverrapporten-nou-2003.pdf. Accessed on 9 February 2017.

NTB. 2011. - Jens, gi gass for olje i nord. NRK. https://www.nrk.no/troms/_jens_-gi-gass-for-olje-i-nord-1.7477941. Accessed on 8 February 2017.

Olsen, Johan P. 1989. Petroleum og politikk: Det representative demokratiets møte med oljealderen. Oslo: Tano forlag.

Olsen, Øystein. 2012. Norges Bank. http://www.norges-bank.no/pages/88046/ arstale_2012.pdf. Accessed on 8 February 2017.

Overland, Indra, and Andrey Krivorotov. 2015. Norwegian-Russian Political Relations and Barents Oil and Gas Developments. In International Arctic 
Petroleum Cooperation: Barents Sea Scenarios, ed. Anatoli Bourmistrov, Frode Mellemvik, Alexei Bambulyak, Ove Gudmestad, Indra Overland, and Anatoly Zolotukhin, 97-96. Abingdon: Routledge.

Pedersen, Anne-Merethe. 2010. Anbefaler varig nei til oljeboring i sårbare havområder. http://naturvernforbundet.no/lofoten-vesteralen-og-senja/ anbefaler-varig-nei-til-oljeboring-i-sarbare-havomrader-article17626-1467. html. Accessed on 3 August 2015.

Ree, Maiken. 2012. Lofoten-ordførere krever åpning. Teknisk Ukeblad. http:// www.tu.no/petroleum/2012/12/14/lofoten-ordforere-krever-apning. Accessed on 27 July 2015.

Regnskogfondet. 2014. Oljefondet investerer 130 milliarder i regnskogødeleggelse. http://www.regnskog.no/no/nyheter/nyhetsarkiv/globalt/oljefondetinvesterer-130-milliarder-i-regnskogs\%C3\%B8deleggelse. Accessed on 10 February 2017.

RORG. 2015. Ti år med etiske retningslinjer (oljefondet). http://www.rorg.no/ Artikler/3218.html. Accessed on 15 March 2017.

Rørstad, Ole Marius, and Markus Thonhaugen. 2014. Ny rapport spår store oljemuligheter i nord. https://www.nrk.no/nordland/ny-rapport-spar-storeoljemuligheter-i-nord-1.12051108. Accessed on 1 November 2016.

Ryggvik, Helge. 2009. Til siste dråpe: Om oljens politiske økonomi. Oslo: Aschehoug.

- 2010. The Norwegian Oil Experience: A Toolbox for Managing Resources? Oslo: TIK.

2011. Norske oljeerfaringer. Oslo: Universitetet i Oslo.

Ryggvik, Helge, and Ole Andreas Engen. 2005. Den skjulte dagsorden, rammer for en alternativ oljepolitikk. Stavanger: SAFE.

Salamon, Lester, Wojciech Sokolowski, Megan Haddock, and Helen Tice. 2013. The State of Global Civil Society and Volunteering: Latest Findings from the Implementation of the UN Nonprofit Handbook. Baltimore, MD: Johns Hopkins University Press.

Salvesen, Geir. 2004. Krass kritikk av Aps Statoil-kurs. Aftenposten, 14 April, p. 13.

Schücking, Helga. 2014. Dirty and Dangerous. The Norwegian Government Pension Fund's Coal Investments. http://www.framtiden.no/rapporter/etikkog-naeringsliv/744-skittent-og-farlig-kull-i-oljefondet/file.html. Accessed on 12 May 2015.

Skredderberget, Asle. 2015. Usannsynlig rik: Historien om Norge og oljefondet. Oslo: Kagge forlag. 
Staavi, Tom. 2015. Lager børs for å tukte turbokapitalistene. $V G$. http://www. vg.no/nyheter/meninger/oljefondet/lager-boers-for-aa-tukte-turbokapitaliste ne/a/23391353/. Accessed on 8 May 2015.

Steigum, Erling. 2002. Oil Price Risk, Prudent Fiscal Policy and Generational Accounting. Bergen: SNF.

Steigum, Erling, and Øystein Thøgersen. 2014. A Crisis Not Wasted: Institutional and Structural Reforms behind Norway's Strong Macroeconomic Performance. Oslo: BI Norwegian Business School.

Stevens, Paul, and Evelyn Dietsche. 2008. Resource Curse: An Analysis of Causes, Experiences and Possible Ways Forward. Energy Policy 36 (1): 56-65.

Store norske leksikon. 2016. Norsk oljehistorie. Store norske leksikon https://snl. no/Norsk_oljehistorie. Accessed on 11 April 2016.

Stortingets industrikomité. 1971. Innstilling fra den forsterkede industrikomité om undersøkelse etter og utvinning av undersjøiske naturforekomster på den norske kontinentalsokker m. m. [sic]. Innst. S. nr. 294.

Thurber, Mark, David Hults, and Patrick Heller. 2011. Exporting the "Norwegian Model": The Effect of Oil Sector Design on Oil Sector Performance. Energy Policy 39 (9): 5366-5378.

Thurber, Mark, and Benedicte Tangen Istad. 2012. Norway's Evolving Champion: Statoil and the Politics of State Enterprise. In Oil and Governance: State-Owned Enterprises and the World Energy Supply, ed. David Victor, David Hults, and Mark Thurber, 599-654. Cambridge: Cambridge University Press.

Tordo, Silvana, Brandon S. Tracy, and Noora Arfaa. 2011. National Oil Companies and Value Creation. Vol. 1. Washington, DC: EBRD/World Bank.

Tranøy, Bent Sofus, and Øyvind Østerud. 2001. En fragmentert stat? In Den fragmenterte staten: Reformer, makt og styring, ed. Bent Sofus Tranøy and Øyvind Østerud, 9-38. Oslo: Gyldendal.

Transparency International. 2015. Corruption Perceptions Index 2015. http:// www.transparency.org/cpi2015. Accessed on 15 December 2016.

Victor, David, David Hults, and Mark Thurber. 2012. Introduction and Overview. In Oil and Governance: State-Owned Enterprises and the World Energy Supply, ed. David Victor, David Hults, and Mark Thurber, 3-31. Cambridge: Cambridge University Press.

Wainberg, Miranda Ferrell, and Michelle Michot Foss. 2007. Commercial Frameworks for National Oil Companies. Austin, TX: University of Texas at Austin. 
Wyller, Thomas Christian. 1973. Norge-En oljestat? In Norge som oljestat, ed. Thomas Christian Wyller, 9-35. Oslo: Gyldendal.

— 1975. Oljen og vårt politiske system. In Norsk oljepolitikk, ed. Kari Bruun Wyller and Thomas Christian Wyller, 153-174. Oslo: Gyldendal.

Wyller, Kari Bruun, and Thomas Christian Wyller. 1975. Innledning. In Norsk oljepolitikk, ed. Kari Bruun Wyller and Thomas Christian Wyller, 8-10. Oslo: Gyldendal.

Open Access This chapter is licensed under the terms of the Creative Commons Attribution 4.0 International License (http://creativecommons.org/ licenses/by/4.0/), which permits use, sharing, adaptation, distribution and reproduction in any medium or format, as long as you give appropriate credit to the original author(s) and the source, provide a link to the Creative Commons license and indicate if changes were made.

The images or other third party material in this chapter are included in the chapter's Creative Commons license, unless indicated otherwise in a credit line to the material. If material is not included in the chapter's Creative Commons license and your intended use is not permitted by statutory regulation or exceeds the permitted use, you will need to obtain permission directly from the copyright holder.

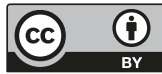

